\title{
Entrepreneurial Competencies and Performance of Dairy Cooperatives in Machakos County, Kenya
}

\author{
Dr. Margaret Nganu $(\mathrm{PhD})^{1^{*}}$ Margaret Musyoka (MBA) $)^{1}$ Benedict Mutuku (Msc) ${ }^{1}$ \\ 1. School of Business, Machakos University, P.O. Box 136, Machakos-90100. \\ * E-mail of the corresponding author: margaretnganu@gmail.com
}

\begin{abstract}
The objective of the study was to establish entrepreneurial competencies and performance of dairy cooperatives in Machakos County, Kenya. Specifically, to establish the extent to which managerial competencies influence performance of dairy cooperatives in Machakos County, Kenya; to determine the extent to which entrepreneurial traits influence performance of dairy cooperatives in Machakos County, Kenya; and to assess the effects of technical skills on performance of dairy cooperatives in Machakos County, Kenya. The study was descriptive. The study was a census of the 15 dairy cooperatives registered under the Lower Eastern Dairy Cooperative Association in Machakos County. The unit of analysis was the cooperatives while the units of observations were the board members of the cooperatives. A standard questionnaire was used to collect primary data from the board members of the cooperatives. Data analysis included frequencies, percentages, and t- tests. The data was analyzed by use of computer statistical packages and data presented in tables and figures. Based on the first study objective, study concludes that there was lack of sufficient evidence to show that managerial competencies have an effect on performance of dairy cooperatives in Machakos County. Based on the second study objective, the study concludes that there is adequate evidence to show that entrepreneurial traits have positive effects on performance of dairy cooperatives in Machakos County. Based on the third study objective, the study concludes that there is adequate evidence to show that technical skills have positive effects on performance of dairy cooperatives in Machakos County. The study recommends development, adoption and full implementation of business and strategic plans for the cooperatives for them to attain sustainable competitiveness and growth. The study also recommends data based product development and diversification. Further training would be critical in building capacity for creativity, risk taking, situational analysis and opportunity identification. Moreover, the study recommends training to enhance employees' capacity and effectiveness in financial management; procurement; production; and marketing. Particularly, loss of revenue due to spoilage of milk can be controlled by training on best processing and quality control methods while training on marketing, would be critical in enhancing product penetration, reducing customer complaints and stimulating positive growth. Finally, further investigations should be conducted to widening the scope of the study to compare Machakos to other parts of the Country and also to identify reasons for high labor turnover and poor public relations between the cooperatives and communities surrounding them.
\end{abstract}

Keywords: Entrepreneurial competency, Performance

DOI: $10.7176 / \mathrm{EJBM} / 11-33-13$

Publication date: November $30^{\text {th }} 2019$

\section{Introduction}

Agricultural sector is the main economic stay in Kenya. The sector directly contributes $26 \%$ and indirectly contributes another 25\% of the Gross Domestic Product (GDP) (Njine, 2014). According to Food and Agriculture Organization (FAO), the sector employs more than 40 per cent of the total population and more than 70 per cent of Kenya's rural people. The sector also accounts for $65 \%$ of export earnings, and provides the livelihood (through employment, income and food security needs) for more than 80 per cent of the Kenyan population. Further, the sector contributes to improving nutrition through production of safe, diverse and nutrient dense foods (FAO, 2018).

According to Intergovernmental Authority on Development (IGAD), based on complete data of 2009 census, livestock sub sector provides nearly half (45\%) of the output from the agricultural sector (IGAD, 2013). In the livestock sector, 2017 annual livestock production report from the State Department of Livestock indicates that milk is Kenya's most economically important livestock product, with dairy farming being the single largest sub sector of agriculture in Kenya. In 2017, 3.3 billion liters valued at Ksh. 182.06 billion was produced, contributing $50 \%$ of the total gross value of livestock's products in Kenya (GOK, 2018). This means that milk alone contributed $7.4 \%$ of Agricultural GDP and accounted for 2.3\% of the country's GDP in 2017 (CBK, 2018). According to Waitituh (2017), dairy sub sector in Kenya is the most rapidly expanding agricultural sub sector in Eastern Africa and an important source of livelihood to approximately 1 million small-scale farmers. 
Situational analysis of dairy subsector in the Kenya National Dairy Master Plan Volume I of 2012 revealed that despite the potential of the dairy sub sector to stimulate and spar economic growth, the sub sector has faced many challenges, which hinder its optimum exploitation (GOK, 2012). Nationally, the challenges include feeding, veterinary services delivery, inadequate breeding services, financial services delivery, challenges in milk production, in extension services delivery and most importantly milk marketing with majority of the smallholders relying heavily on dairy cooperative societies for the market of their milk (Mwangi, 2013).

In Machakos County, annual milk production is estimated at 35 million liters valued at Ksh. 2.1 billion (GOK, 2018). The dairy subsector directly employs more than 10,000 farmers in the County and according to industry estimates; it creates additional 7,700 farm jobs and 3,500 jobs along the milk handling and marketing value chain nodes (Muriuki, 2011). According to the department of Agriculture and Food Security (DAFS) of Machakos County, milk is sold through 15 registered milk cooperatives, several milk bars, hawkers and directly at the farm gate. However, despite an increased demand for milk, marginal incomes by cooperatives in the county has remained low over the past 10 years (DAFS, 2017).

Shangurai (2013) identifies inadequate entrepreneurial skills and marketing as the main challenges hindering efficient performance of dairy cooperatives. These challenges are barriers to improvement of market competitiveness of the dairy cooperative for increased income generation to farmers. According to Díaz-Pichardo, et al. (2012), the concept of entrepreneurial competencies in agricultural cooperatives deserves special attention as lack of entrepreneurial competencies may restrict cooperatives from effectively dealing with competition or in achieving more efficient production models, market and product development. Therefore, in order to improve the market competitiveness of dairy cooperatives for increased income generation and sustainable development, this study identifies entrepreneurial competencies among members and cooperative management to be of paramount importance.

By developing entrepreneurial competency, dairy cooperatives are expected to work in an organized manner and develop sustainable competitive advantages in order to compete successfully in regional, national and international markets (Díaz-Pichardo, et al., 2012).Since operations of dairy cooperatives are non-homogeneous and context based, within the context of Machakos County, the study first sought to establish entrepreneurial competency levels and their effects on performance of dairy cooperatives in Machakos County, Kenya.

\subsection{Study Objectives}

The general objective of the study was to establish entrepreneurial competencies and performance of dairy cooperatives in Machakos County, Kenya.

The specific objectives are;

1. To establish the extent to which managerial competencies influence performance of dairy cooperatives in Machakos County, Kenya.

2. To determine the extent to which entrepreneurial traits influence performance of dairy cooperatives in Machakos County, Kenya.

3. To assess the effects of technical skills on performance of dairy cooperatives in Machakos County, Kenya.

\subsection{Empirical Literature Review}

Research on the development of entrepreneurial competencies in dairy cooperatives is scarce, especially in emerging economies such as Kenya. Although its implications in public policy have been discussed thoroughly in these economies, several dimensions of entrepreneurial competencies in dairy cooperatives require more detailed research including management skills, entrepreneurial skills and technical skills (Díaz-Pichardo, Cantú-González, López-Hernández, \& McElwee, 2012).

A study by Dana and Schoeman (2010) sought to identify entrepreneurial innovations adopted by dairy cooperatives in New Zealand. The study found out that changes in the external operating environment motivated some cooperatives to merge into mega cooperatives through horizontal and vertical integration in order to ensure sufficient efficiencies and economies of scale, to secure the international competitiveness. These merges moved competition from between domestic cooperatives to between international businesses.

A case study on Mulkanoor in India by Reddy(2014) explore the entrepreneurial competencies among rural women dairy cooperatives. The study demonstrated early success of the women group in earning surpluses and supply of quality milk at competitive price. Some of strategies used by the group included focus on minimizing cost of transportation, prompt payment to milk suppliers, farmer support systems such as input supply, veterinary services, loans and insurance. These conferred individual economic/social benefits through micro-enterprises and raised self-confidence and experience to launch bigger ventures in the future. The study was however, based on a case study of one cooperative. 
In Zimbabwe, Shangurai (2013) evaluated performance of Hamaruomba smallholder dairy cooperative for improved dairy value chain. The study revealed that level of milk production in Masvingo district was very low and the cooperative was operating below capacity because cooperative members are producing low volumes of milk, which is further worsened by side selling. The study also observed that inadequate entrepreneurial skills, costs and marketing are the main challenges hindering efficient performance of dairy cooperative. These challenges are barriers to improve the market competitiveness of the dairy cooperative for increased income generation to farmers.

In Kenya, a study by Mwangi (2013) investigated the factors influencing dairy cooperatives performance in Mathira and Kieni Constituencies in Nyeri County. The study identified entrepreneurial competencies such as marketing skills, innovation and value addition as the major bottlenecks in creating niche markets and achieving competitive advantages. However, a study by Muriithi, Huka and Njati (2014) explored the factors influencing growth of dairy farming business in Amentia South District of Meru County, Kenya. The study established that business management skills influence growth of diary enterprises and that interaction with extension service providers positively influenced the earnings of the dairy farmers. Further the study showed that joint ventures between dairy farming and horticultural crop growing was beneficial as it offered complementary benefits through use of manures for horticulture.

A study by Osewe, Kharde and Kipsat (2016) sought to establish entrepreneurial behavior of dairy groups in Nyamira County. The study measured entrepreneurial behavior as a composite index of attitude toward dairy entrepreneurship; attitude towards dairy farming and Smallholder Dairy Commercialization Program (SDCP); and innovativeness. The study established a relationship between the program and entrepreneurial behavior of the dairy groups. Majority of the respondents were in survival stage of entrepreneurial growth where the businesses demonstrated potential viability with an established market niche. The owners were mostly concerned about the relationship between revenues and expenses so as to break even and have sufficient funds to maintain the capital assets.

Despite, these findings providing insightful information, there still lack empirical evidence to show the level of entrepreneurial competency among the dairy cooperatives in Machakos County and their influence on performance. Particularly, more information is required on how managerial skills, entrepreneurial skills and technical skills influence performance of dairy cooperatives in Machakos County. The findings will be significant in providing information on how to enhance entrepreneurial capabilities among these cooperatives for improved livelihoods, income and sustainable development.

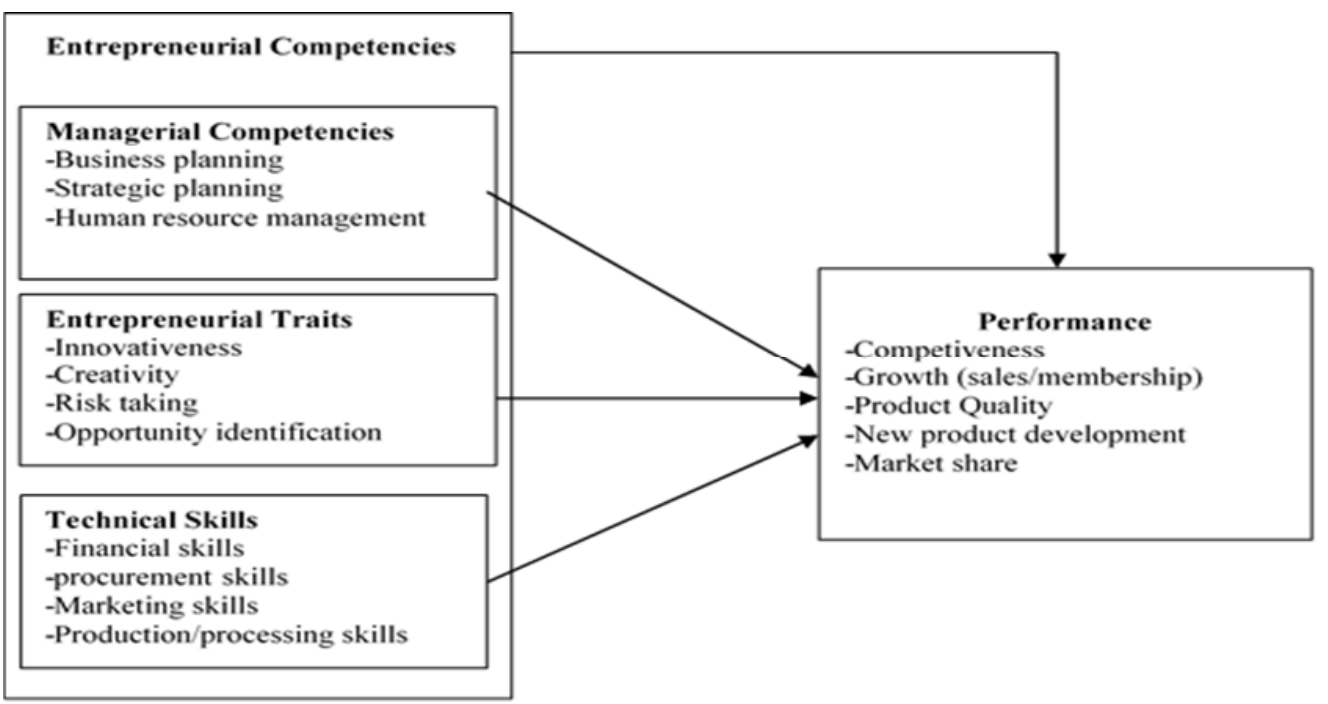

Figure 1: Conceptual Framework

\subsection{Methodology}

The study adopted a mixed research design for collecting primary and secondary quantitative and qualitative data. Use of this method was critical in data cross validation and verification. A questionnaire was used to collect primary data from the board members of the cooperatives. The target population was the registered 15 cooperatives in Machakos County. A census was conducted for all the boards. The study population was small, thus each board was represented by the chairpersons, secretary, treasurer and managers for those cooperatives with managers. 


\subsection{Results and Discussions}

4.1 General Information

Findings in Table 1 indicates that the study achieved $80 \%$ response rate. Respondents on behalf of the cooperatives consisted of chairpersons (50\%), secretaries (16.7\%), treasurers $(8.3 \%)$ and cooperative managers $(25 \%)$. The representation was considered adequate as the response was from nearly all registered cooperatives $(80 \%)$ in the county. Further, the officials were well knowledgeable about the cooperatives and had access to records for clarifications. Table 1 also shows that $41.7 \%$ of the cooperatives were startups (less than 5 years old) and $41.5 \%$ had been in operation for more than 10 years. Meanwhile only $16.7 \%$ had been in existence for between 5 and 10 years. Table 1 further indicates that one third of the cooperatives had membership of less than $50,41.7 \%$ had membership of between 50 and 100 while $25 \%$ had more than 100 members. These findings illustrates a fairly young industry with limited membership. Despite majority of the cooperatives being young, the findings also indicated that all these cooperatives had grown from self-help groups before federating to form a cooperative. This indicated a positive growth and response to call for stronger farmer organizations.

Table 4: General Information

\begin{tabular}{|c|c|c|}
\hline Variable & Category & Percentages \\
\hline \multicolumn{2}{|l|}{ Response Rate } & $80 \%$ \\
\hline \multirow[t]{4}{*}{ Position of Respondent } & Chair & $50 \%$ \\
\hline & Secretary & $16.7 \%$ \\
\hline & Treasurer & $8.3 \%$ \\
\hline & Manager & $25 \%$ \\
\hline \multirow[t]{3}{*}{ Age of the Cooperative } & $<5$ years & $41.7 \%$ \\
\hline & 5-10 years & $16.7 \%$ \\
\hline & $>10$ years & 41.5 \\
\hline \multirow[t]{3}{*}{ Membership } & $<50$ & $33.3 \%$ \\
\hline & $50-100$ & $41.7 \%$ \\
\hline & $>100$ & $25 \%$ \\
\hline
\end{tabular}

Figure 2 shows that in nearly all the cooperatives, men were more than women. On average $69 \%$ of the members were males while $31 \%$ female indicating a male dominated industry. This is unsurprising as investment in dairy industry is capital intensive, a resource requirement that does not favor rural females due to the high financial disparity between males and females in the rural areas. Despite, females are known to offer significant contribution in the dairy sector through labor and management. Thus, there is need to encourage more female leadership among the cooperatives.

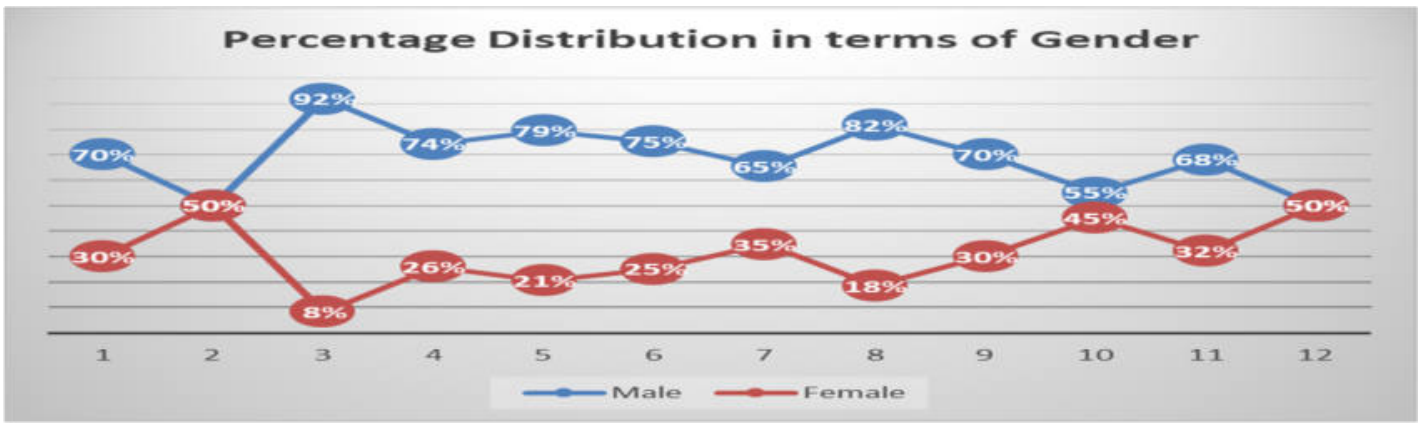

Figure 2: Percentage distribution of members by Gender

\subsection{Board of Managements' Capacity}

The study revealed that the largest board had ten members while the smallest board had five members with majority $(83 \%)$ of the boards having between seven and ten members. Eight was the modal board size. On average, each board had five male members and three female members. However, only $42 \%$ of the boards met the minimum requirement of at least one-third representation of either gender. Reflective of the cooperatives' male dominant membership. Majority of the boards (58\%) failed the minimum threshold as they have more than two-thirds representation by men. 


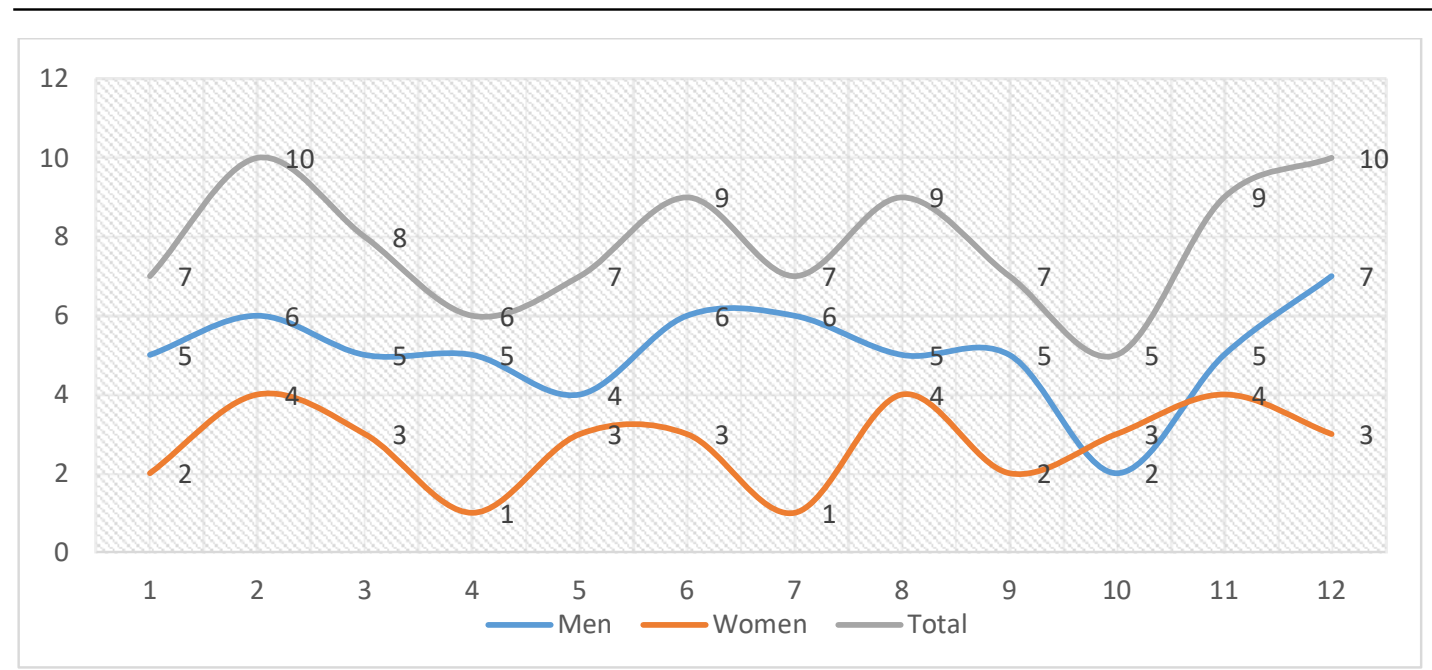

Figure 3: Cooperative Boards' Composition

The findings revealed that majority of the board members in the cooperatives are aged between 46 and 75 years. Despite, Table 2 indicates that $25 \%$ of the boards indicated that they have at least 1 youth (18-35 years) in the board and $66.7 \%$ indicated that they have members aged below 55 years. This distribution shows that for most cooperatives, there is an opportunity for varied views from across different age cohorts. Presence of younger board members would also facilitate succession management.

Table 5: Age of Board Members

\begin{tabular}{|l|l|l|l|}
\hline Category & Youngest Board member & Oldest Board member & Majority of the Board members \\
\hline $18-35$ years & $25 \%$ & - & - \\
\hline $36-45$ years & $16.7 \%$ & - & - \\
\hline $46-55 \%$ & $25 \%$ & - & $36.4 \%$ \\
\hline $56-65$ years & $8.3 \%$ & $18.2 \%$ & $27.3 \%$ \\
\hline $66-75$ years & $16.7 \%$ & $36.4 \%$ & $36.4 \%$ \\
\hline Above 75 years & $8.3 \%$ & $45.5 \%$ & - \\
\hline
\end{tabular}

Table 3 indicates that for majority $(82 \%)$ of the cooperatives chair persons have three years term. Similarly, majority of the board secretaries (67\%) and board treasurers (80\%). Table 3 also shows that 18\% of the board chairpersons have served for more than two consecutive terms while $16 \%$ of the secretaries have served for more than two consecutive terms. Likewise $20 \%$ of the treasurers. This indicates that at least $20 \%$ of the firms rarely change their leadership. This makes the leaders and members get used to doing the same thing the same way with minimal progress and growth.

Table 6: Term of Office

\begin{tabular}{|c|c|c|c|c|c|c|c|c|c|}
\hline \multirow[t]{2}{*}{ Office Bearer } & \multirow{2}{*}{$\begin{array}{l}\text { Term of } \\
\text { Office }\end{array}$} & \multicolumn{7}{|c|}{ Actual Continuous Term in Office } & \multirow[t]{2}{*}{ Total } \\
\hline & & 1.5 & 2 & 3 & 6 & 8 & 15 & 18 & \\
\hline \multirow[t]{3}{*}{ Chair } & 1 & - & $9 \%$ & - & - & - & - & - & $9 \%$ \\
\hline & 3 & $18 \%$ & $9 \%$ & $27 \%$ & $9 \%$ & $9 \%$ & $9 \%$ & - & $82 \%$ \\
\hline & 6 & $0 \%$ & - & $9 \%$ & - & - & - & - & $9 \%$ \\
\hline \multirow[t]{3}{*}{ Secretary } & 1 & - & $8 \%$ & - & - & - & $8 \%$ & - & $17 \%$ \\
\hline & 3 & $8 \%$ & $8 \%$ & $33 \%$ & $8 \%$ & $8 \%$ & - & - & $67 \%$ \\
\hline & 6 & - & - & $8 \%$ & - & - & $8 \%$ & - & $17 \%$ \\
\hline \multirow[t]{3}{*}{ Treasurer } & 1 & - & $10 \%$ & - & - & - & - & - & $10 \%$ \\
\hline & 3 & $10 \%$ & $10 \%$ & $30 \%$ & - & - & $10 \%$ & $10 \%$ & $80 \%$ \\
\hline & 6 & - & - & - & - & - & - & - & $10 \%$ \\
\hline
\end{tabular}

\section{Board Members' Level of Education}

The study established that majority (31\%) of the boards had secondary education as the highest academic qualification for $95 \%$ of their members. However, $23 \%$ of the boards had post-secondary education certificate as the highest academic qualification for $21 \%$ of their members with $54 \%$ being secondary certificate holders and $25 \%$ primary school certificate holders. Despite, $46 \%$ of the cooperatives indicating that they have some board members with university degrees, there was only $15 \%$ representation of degree holders in this category, $3 \%$ representation 
of diploma holders, $42 \%$ post-secondary certificate holders, $27 \%$ representation of secondary certificate holders and $12 \%$ of primary school certificate holders. In general, Figure 4 shows that $13 \%$ of the board members had primary education as their highest academic qualification, 58\% secondary education, 21\% post-secondary certificate, $1 \%$ Diploma and $7 \%$ university degrees. These findings reveal that majority of the boards members have limited academic exposure. This would limit their capacity for systematic decision-making.

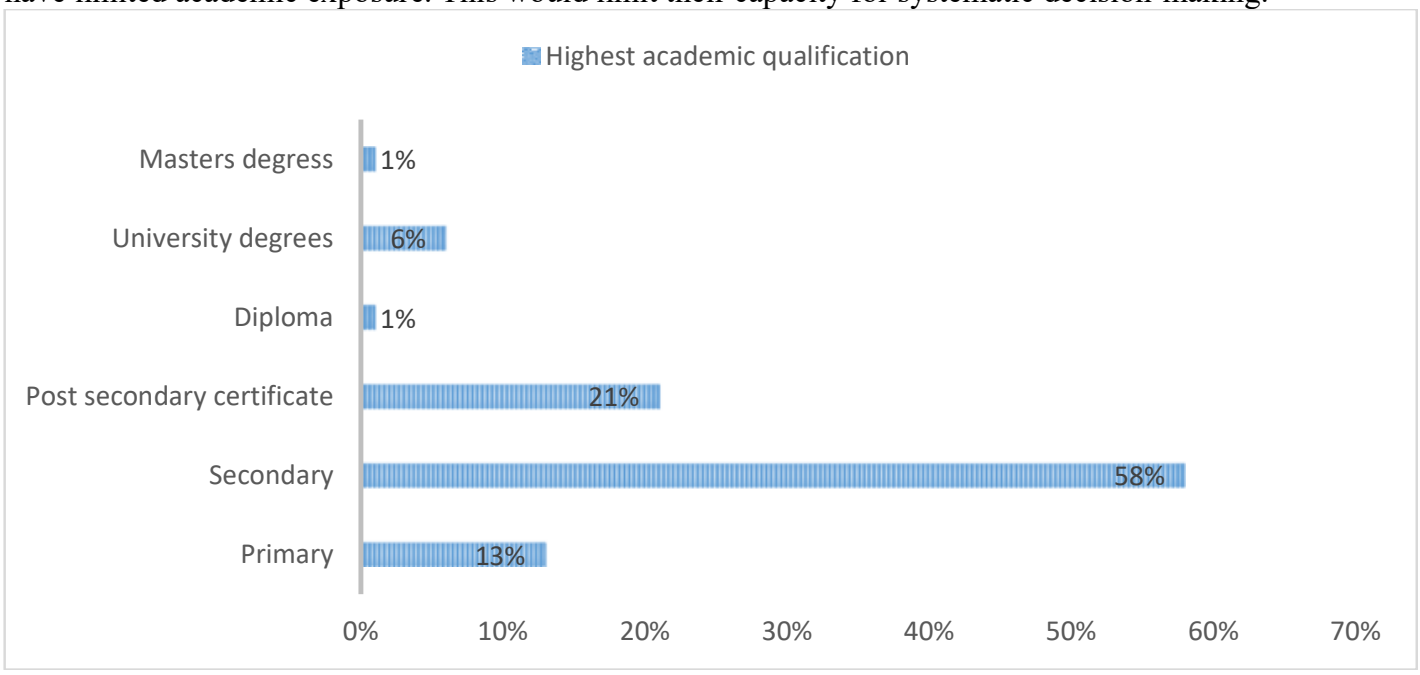

Figure 4: Board' Highest Academic Qualification

Figure 5 shows that $50 \%$ of the boards had at least one person trained on business management, crops production and livestock production respectively. Forty two percent of the boards have at least one member trained on animal health and general management respectively. Likewise $17 \%$ of the boards have at least one member trained on accounting while $8 \%$ on public health. In general, Figure 5 also shows that majority of the trained board members $(23 \%)$ have training on crops and livestock production while $18 \%$ are trained on animal health, $14 \%$ on general management, $5 \%$ on accounts and $2 \%$ on public health. In summary, level of education for majority was secondary with very few post-secondary education.

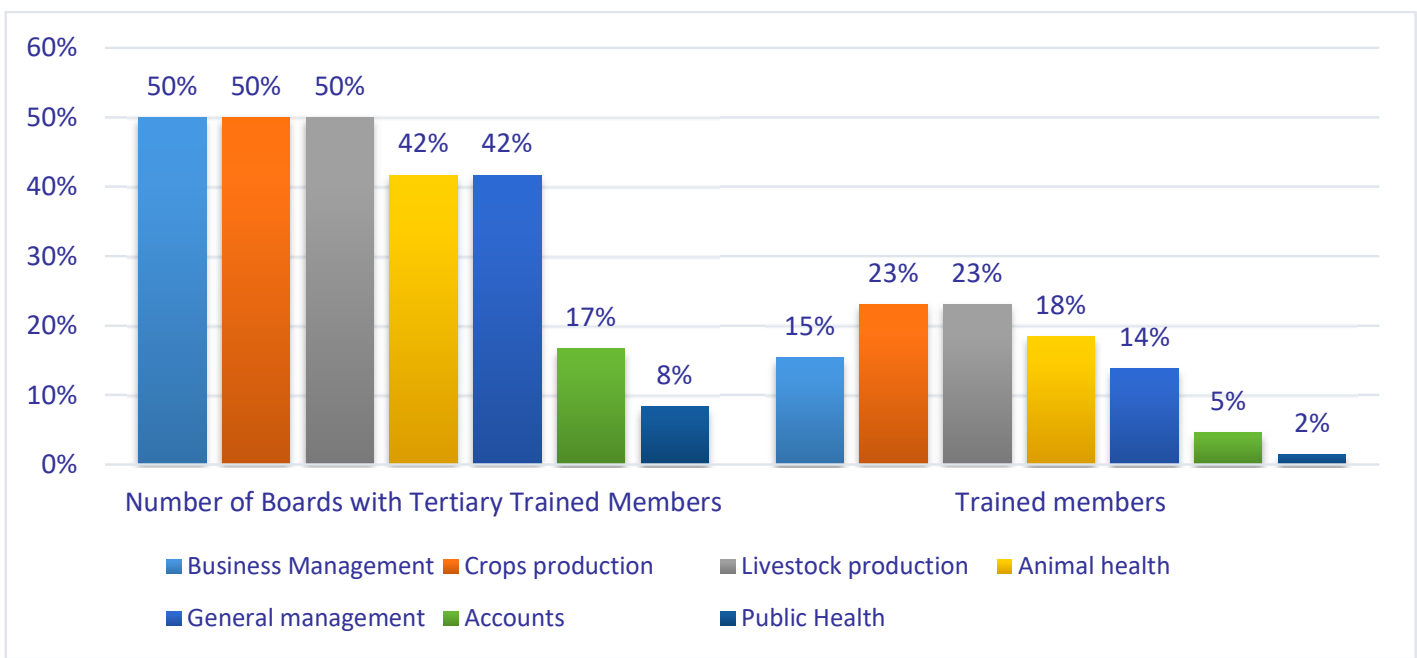

Figure 5: Training of Board Members

Figure 6 shows that $25 \%$ of the cooperatives did not have any sub committees. Forty two percent (42\%) had executive and supervisory sub committees. Seventeen percent had executive, supervisory and training sub committees. Seventeen percent had executive, marketing, AI, and stores sub committees. Seventeen percent had executive, marketing and stores sub committees. In a nutshell, most cooperatives operated with only the executive sub committees who had no managerial training. Hence, more sub committees would be required for effective oversight and training for the executive sub-committee and empowering of the supervisory and training subcommittees. 


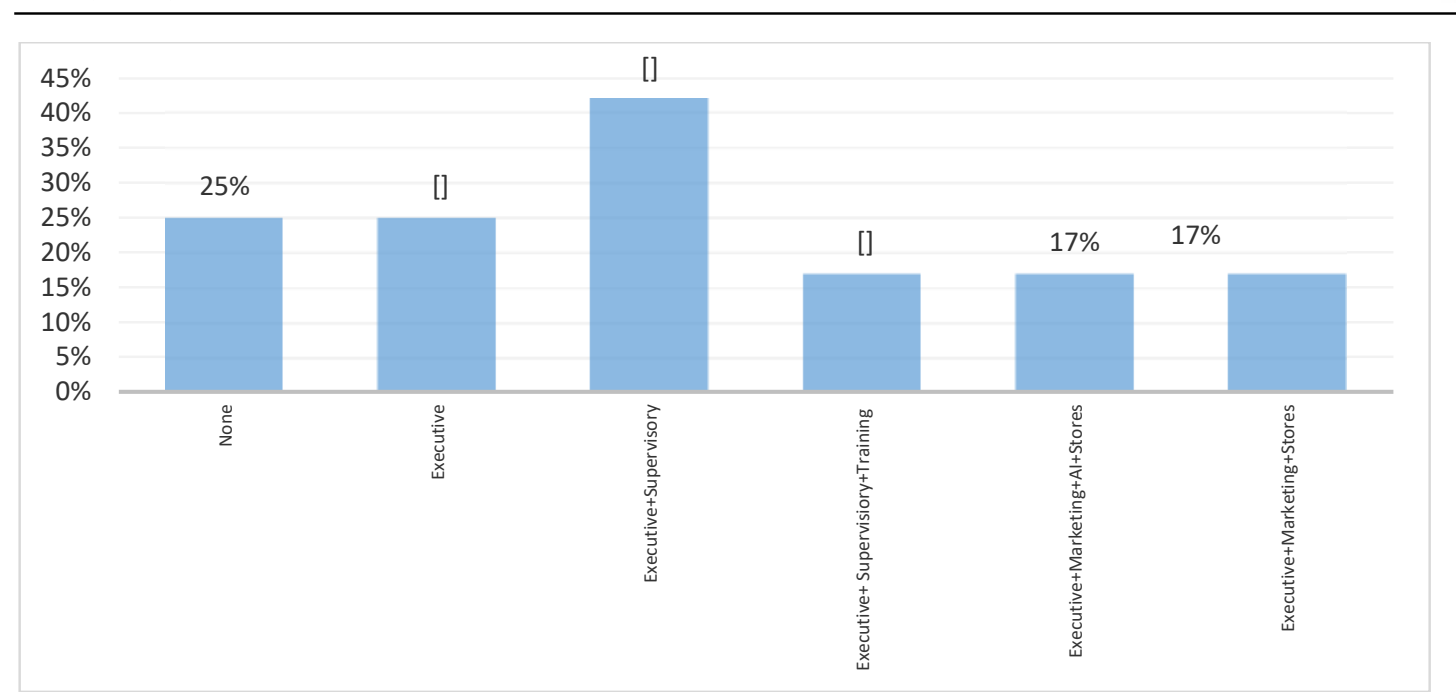

Figure 6: Presence of Sub Committees

\subsection{Management Capacity}

The study sought to establish the level of management capacity in the dairy cooperative boards. Table 4 shows that $58 \%$ of the cooperatives have not formally employed a manager. For those with managers $80 \%$ of the managers are males, $40 \%$ of the managers are youth (18-35 years), $20 \%$ are aged between 36 and 45 years, $20 \%$ are aged between 46 and 55 years while 20\% are aged between 56 and 65 years. Sixty percent of the managers have secondary education as their highest academic qualification while $20 \%$ are diploma holders and $20 \%$ have Masters' degrees as their highest academic qualification.

Further, Table 4 indicates that $20 \%$ of the managers have no additional formal training apart from the secondary education. Forty percent of the managers are trained on dairy production while $20 \%$ are milk handling and safety, $20 \%$ on cooperative management and $20 \%$ on project management. In summary, most managers have secondary education with few having post-secondary education. None had diploma or degree in cooperative management of business management, which would improve the performance of the cooperatives.

Table 7: Management Qualification and Experience

\begin{tabular}{|l|l|l|}
\hline Variable & Response & Percentage \\
\hline Employs manager & Yes & $42 \%$ \\
\hline Gender of Manager & Male & $80 \%$ \\
\cline { 2 - 3 } & Female & $20 \%$ \\
\hline \multirow{4}{*}{ Age of Manager } & $18-35$ years & $40 \%$ \\
\cline { 2 - 3 } & $36-45$ years & $20 \%$ \\
\cline { 2 - 3 } & $46-55$ years & $20 \%$ \\
\cline { 2 - 3 } Manager & $56-65$ years & $20 \%$ \\
\hline \multirow{4}{*}{ Manager's field of training } & Secondary & $60 \%$ \\
\cline { 2 - 3 } & Diploma & $20 \%$ \\
\cline { 2 - 3 } & Masters & $20 \%$ \\
\cline { 2 - 3 } & No formal training & $20 \%$ \\
\cline { 2 - 3 } & Dairy production & $40 \%$ \\
\cline { 2 - 3 } & Milk handling \& safety & $20 \%$ \\
\cline { 2 - 3 } & Cooperative management & $20 \%$ \\
\cline { 2 - 3 } & Project planning \& management & $20 \%$ \\
\hline \multirow{3}{*}{ Manager's experience $i n$} & Less than 2 years & $20 \%$ \\
\cline { 2 - 3 } & $5-10$ years & $20 \%$ \\
\cline { 2 - 3 } & $10-15$ years & $40 \%$ \\
\cline { 2 - 3 } & Above 20 years & $20 \%$ \\
\hline
\end{tabular}

\subsection{Operational Capacity}

Milk Handled Per Day

Two thirds $(67 \%)$ of the dairy cooperatives receive and sell less than 500 liters of milk per day while $17 \%$ handle between 500 and 1000 liters, 8\% between 1000-2000 liters and 7\% between 2000 and 3000 liters daily. This 
implies that the cooperatives are very small. From observations, some cooperatives were having equipment that were not being used due to low quantities of milk. Further, the amount of milk handled by most cooperatives was below 1,000 liters per day, hence the need for stimulating more production to take advantage of the existing equipment and economies of scale.

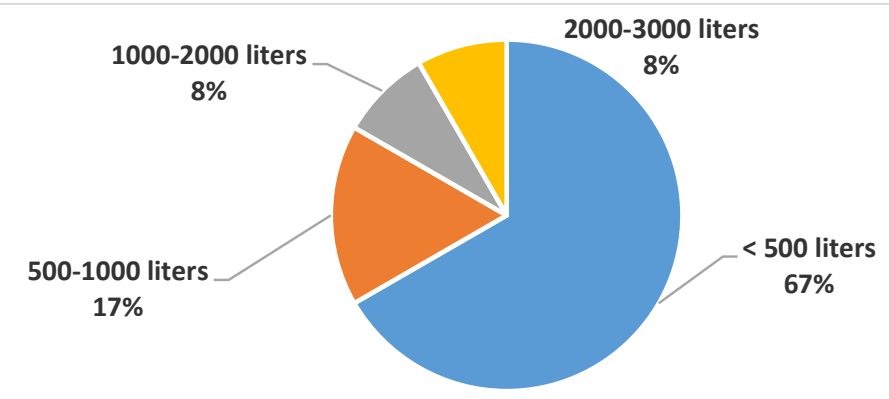

Figure 7: Amount of Milk Handled per day

\section{Cooperatives' Net Worth}

Nearly one-third (30\%) of the dairy cooperatives have a net worth of less than Ksh. 0.5 million. Thirty percent has a net worth of between Ksh. 5 and 10 million. Twenty percent of the cooperatives were valued at more than Ksh. 10 million while $10 \%$ were valued either between Ksh. 0.5 and 1 million or between Ksh. 1 and 5 million respectively.

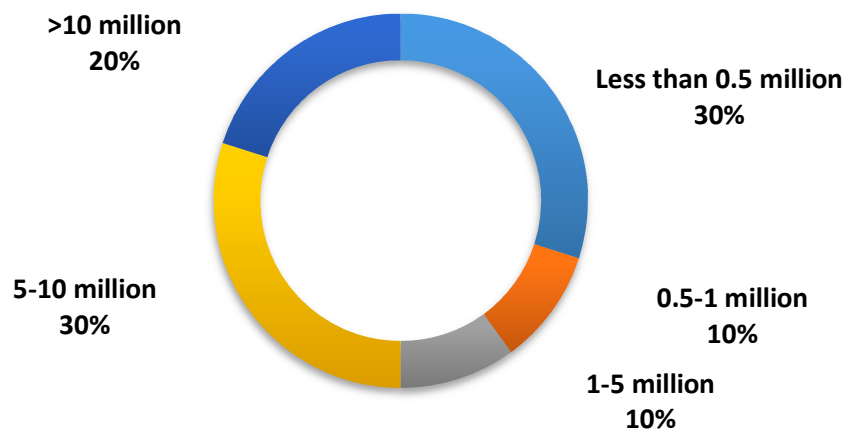

Figure 8: Cooperatives' Net Worth

\section{Products Sold}

Table 5 illustrates that all the cooperatives sell raw milk on a daily basis. However, only $8 \%$ of the cooperatives sell pasteurized milk but occasionally. Sixteen percent of the cooperatives make and sell yoghurt daily. Fifty eight percent of the cooperatives make and sell mala, of which $85 \%$ do it daily and $15 \%$ rarely. Since all cooperatives sell raw milk, this means that the cooperatives can only operate within a small geographical region, thus reducing their competitive advantages.

Table 8: Products Sold

\begin{tabular}{|l|l|l|l|l|}
\hline Product & Cooperatives & Daily Sold & Occasionally Sold & Rarely Sold \\
\hline Raw milk & $100 \%$ & $\mathbf{1 0 0} \%$ & - & - \\
\hline Pasteurized milk & $8 \%$ & - & $\mathbf{1 0 0} \%$ & - \\
\hline Yoghurt & $16 \%$ & $\mathbf{1 0 0} \%$ & - & - \\
\hline Mala & $58 \%$ & $\mathbf{8 5 \%}$ & - & $\mathbf{1 5 \%}$ \\
\hline
\end{tabular}

\section{Source of Funds}

Fifty eight percent of cooperatives exclusively sell dairy products while $42 \%$ sell dairy products and farm inputs. For dairy cooperatives selling farm inputs, the average revenue from farm inputs sales is $21 \%$. Only three firms indicated that they receive funds from the government contributing less than five percent of their total annual revenues. Further only one cooperative indicated that they have an outstanding un-serviced loan. The findings show that diversification of milk products is low. Hence, need for diversification and product development to improve performance. Cooperative can also venture into sale of farm input to increase their incomes. 
Table 9: Products Sold

\begin{tabular}{|l|l|l|l|}
\hline Product & Cooperatives & $\begin{array}{l}\text { Average Sales from Dairy } \\
\text { Products }\end{array}$ & $\begin{array}{l}\text { Average Sales from Farm } \\
\text { inputs }\end{array}$ \\
\hline Dairy products & $58 \%$ & $100 \%$ & $100 \%$ \\
\hline Dairy + Farm inputs & $42 \%$ & $79 \%$ & $21 \%$ \\
\hline
\end{tabular}

\section{Records}

All cooperatives indicated that they keep financial records. All cooperatives keep cash records but only $75 \%$ have bank statements, $50 \%$ keep payment receipts, $42 \%$ keep profits and loss accounts, cash flow records and payment vouchers. One third keep credit records. These findings illustrates inadequacies in record keeping a factor that would limit access to finances. The finding highlights that record management is a main challenge across most of the cooperatives, hence need to have those maintaining record trained proper record keeping.

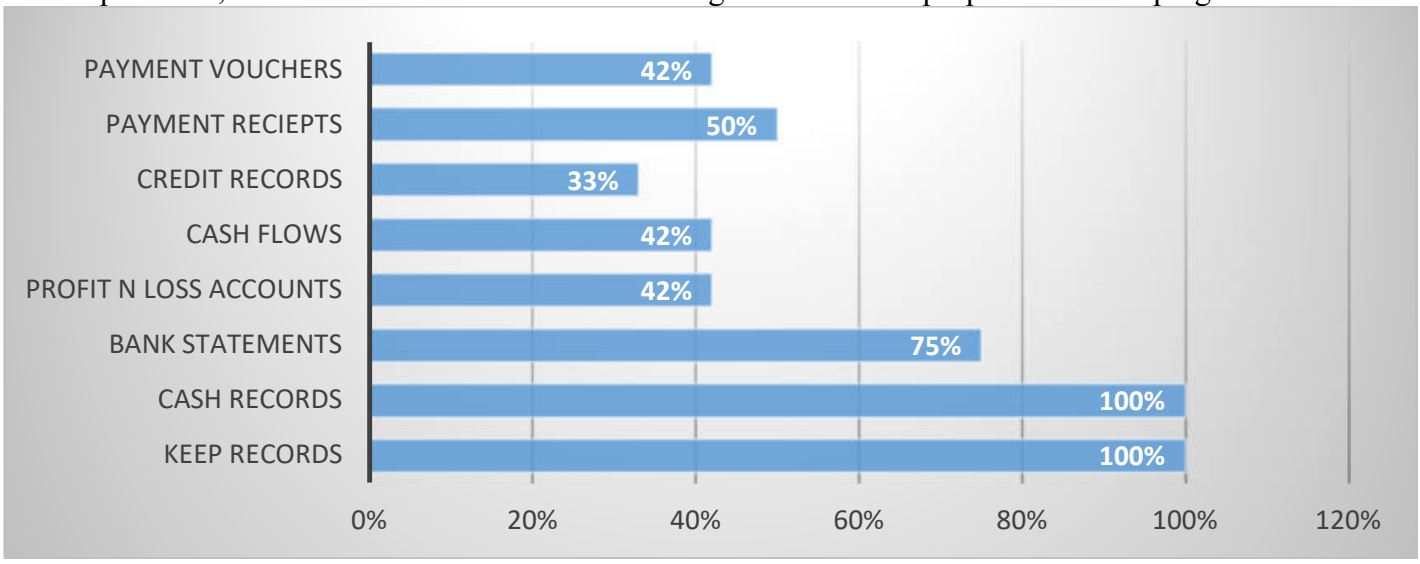

Figure 9: Record Keeping

Capacity of Persons Keeping and Verifying Records

The findings indicated that in 33\% of the dairy cooperatives, managers keep financial records while in $17 \%$ they are kept by accountants, in $25 \%$ by sales persons, in $17 \%$ by board secretaries, in $8 \%$ by board treasurers. This shows that in $25 \%$ of the firms there are no separation of roles between management and the board. This limits oversight.

Figure 10 shows that in $8 \%$ of the cooperatives, managers verify financial records, in $17 \%$ by accountants, in $33 \%$ by board secretaries, $17 \%$ by board chairpersons, $17 \%$ by board secretaries and $8 \%$ by auditors. This shows that there is some level of control in the cooperatives albeit limited. Hence, need to improve record management.

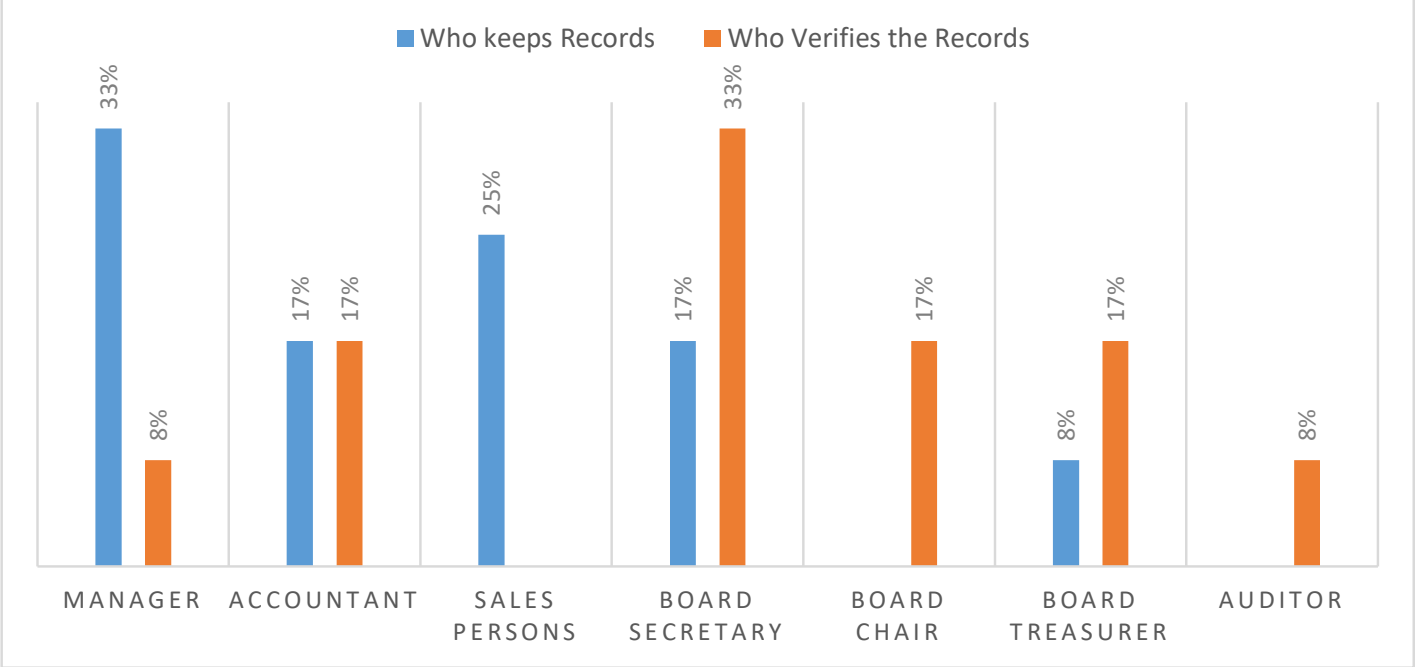

Figure 10: Record Keeping and Verification

Education Level of Persons Keeping Financial Records

The study showed that in 59\% of the cooperatives, financial records are kept by persons with secondary education 
as their highest academic qualification, in $25 \%$ by persons having post-secondary certificates and in $8 \%$ by diploma holders and $8 \%$ by degree holders. Need to train members of staff on record management to avoid either misappropriation of funds or documents.

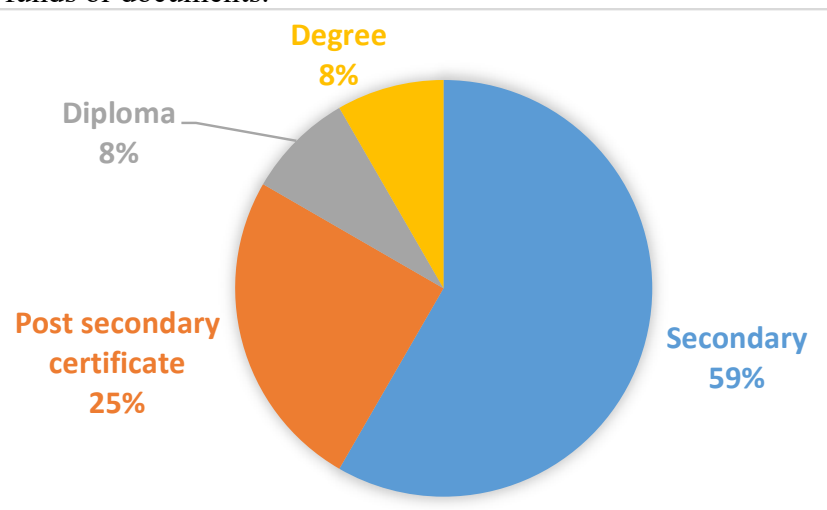

Figure 11: Education Level of Persons Keeping Financial Records

Financial Safeguards and Integrity

The study reported that $50 \%$ of dairy cooperative boards audit their financial records on a monthly basis while $33 \%$ of the boards audit their financial records quarterly and $17 \%$ weekly. However, the misappropriations as rare, minimal and are mostly related to poor record keeping. Thirty eight percent of the cooperatives indicated that financial misappropriations have been reported. Only two cooperatives reported losses above Ksh. 10,000 in the past one year.

Table 10: Financial Audits

\begin{tabular}{|l|l|l|}
\hline Statement & Variable & Score (\%) \\
\hline \multirow{2}{*}{$\begin{array}{l}\text { Frequency of Financial statement audit by the } \\
\text { board }\end{array}$} & Weekly & $17 \%$ \\
\cline { 2 - 3 } & Monthly & $50 \%$ \\
\cline { 2 - 3 } & Quarterly & $33 \%$ \\
\hline Reports for misappropriation & Yes & $38 \%$ \\
\hline
\end{tabular}

\subsection{Entrepreneurial Competencies}

4.5.1 Managerial Competencies

\subsubsection{Business Planning}

The study revealed that none of the cooperatives interviewed have operational business plans in place. This would greatly hamper the cooperatives ability in managing their operations and sourcing for funds. Table 8 shows that at least in $50 \%$ of the cooperatives, daily, customers fail to buy milk because stock have run out. This is a weekly occurrence in $8 \%$ of the cooperatives and also a monthly occurrence in $8 \%$ of the cooperatives. This is either an indicator of poor stock planning or inadequate milk to sell. Likewise, Table 8 indicates that on a daily basis in $25 \%$ of the cooperatives customers are forced to wait for milk deliveries for them to buy. This is also a weekly occurrence in $17 \%$ of the cooperatives and a monthly occurrence in $8 \%$ of the cooperatives. Product spoilage is also recorded daily in $8 \%$ of the cooperatives, weekly in $17 \%$ and monthly in $17 \%$ of the cooperatives. Thus, there is need to develop business plans and ensure their implementation.

Table 11: Business Planning

\begin{tabular}{|c|c|c|c|c|c|c|}
\hline \multirow[t]{2}{*}{ Occurrence } & \multicolumn{4}{|c|}{ At least once in.... } & \multirow[t]{2}{*}{ Rarely } & \multirow{2}{*}{$\begin{array}{l}\text { None } \\
\text { reported }\end{array}$} \\
\hline & Day & Week & 2 weeks & Month & & \\
\hline $\begin{array}{l}\text { Customers fail to buy because the products } \\
\text { have been sold out }\end{array}$ & $50 \%$ & $8 \%$ & $0 \%$ & $8 \%$ & $34 \%$ & $0 \%$ \\
\hline $\begin{array}{l}\text { Customers have to wait for delivery because } \\
\text { products have been sold out }\end{array}$ & $25 \%$ & $17 \%$ & $0 \%$ & $8 \%$ & $50 \%$ & $8 \%$ \\
\hline Product spoilage recorded & $8 \%$ & $17 \%$ & $17 \%$ & $0 \%$ & $50 \%$ & $8 \%$ \\
\hline Average Score & $28 \%$ & $14 \%$ & $6 \%$ & $5 \%$ & $45 \%$ & $5 \%$ \\
\hline
\end{tabular}


Price competitiveness

Forty percent of the cooperatives indicated that their prices are cheaper than their competitors', while $30 \%$ indicated that their prices are either same or premium. This shows variation in pricing among the cooperatives and their competitors. A strategy used to attain competitiveness.

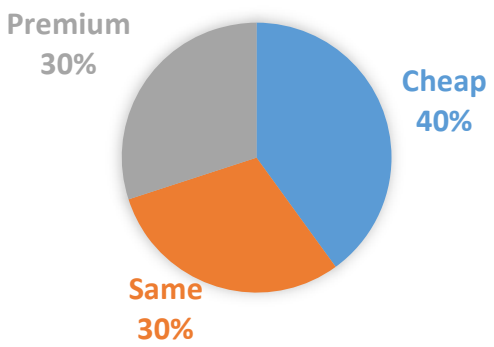

Figure 12: Price Competitiveness

Table 9 shows that one third of the cooperatives have a monthly advertisement campaigns for their products while $9 \%$ have annual advertisement campaigns mostly in the form of word of mouth, posters and customer referrals. Table 9 also indicates that $17 \%$ of the cooperatives conduct market surveys on a monthly basis while $8 \%$ conduct annual market surveys through the word of mouth. The study also revealed that all cooperatives record about $20 \%$ customer complaints.

Table 12: Advertisements \& Market Survey

\begin{tabular}{|l|l|l|l|l|l|}
\hline \multirow{2}{*}{ Occurrence } & \multicolumn{2}{|l|}{ At least once in a... } & \multirow{2}{*}{ Type } \\
\cline { 2 - 5 } & Month & Quarter & Year & None & \\
\hline Advertisement & $33 \%$ & $0 \%$ & $8 \%$ & $59 \%$ & Posters, word of mouth \\
\hline Market survey & $17 \%$ & $0 \%$ & $8 \%$ & $75 \%$ & Word of mouth \\
\hline
\end{tabular}

\subsubsection{Strategic Planning}

The study revealed that only $17 \%$ of the cooperatives had a strategic plan. Out of these, $50 \%$ indicated that they hire consultants to do situational analysis while $50 \%$ indicated that the board and staff conduct situational analysis. When asked the extent to which the strategic plans are implemented, 50\% of the cooperatives having strategic plans said it is below $20 \%$ while $50 \%$ do not measure the extent of implementation. Table 10 also shows that in $50 \%$ of the cooperatives having strategic plans, vision is understood only by the board and in the other $50 \%$ only by the board and staff, that is cooperative members lack an understanding of the vision. Finally, Table 10 indicates that $75 \%$ of the dairy cooperatives store their documents in hard copies while $25 \%$ keep in both hard and soft copies. Hence, need for strategic planning and their full implementation.

The findings indicate that majority of the cooperatives (eight out of ten) do not have operational strategic plans in place. For the few dairy cooperatives with strategic plan documents, they lack capacity for the implementation of these plans as 50\% hire consultants to do situational analysis and 50\% either do not measure implementation status or recorded below $20 \%$. Overreliance on hard copy records also reduces efficiency of strategic decision-making.

Table 13: Strategic Planning

\begin{tabular}{|l|l|l|}
\hline Statement & Variable & Score \\
\hline Have a strategic plan & Yes & $17 \%$ \\
\hline \multirow{2}{*}{ Who conducts situational analysis } & Hired consultants & $50 \%$ \\
\cline { 2 - 3 } & Board together with staff & $50 \%$ \\
\hline \multirow{2}{*}{ Extent of strategic plan implementation } & $<20 \%$ & $50 \%$ \\
\cline { 2 - 3 } & Not measured & $50 \%$ \\
\hline \multirow{2}{*}{$\begin{array}{l}\text { Who fully understand the cooperative } \\
\text { vision }\end{array}$} & Board only & $50 \%$ \\
\cline { 2 - 3 } How business records are stored & Board and staff only & $50 \%$ \\
\cline { 2 - 3 } & Hard copies & $75 \%$ \\
\cline { 2 - 3 } & Hard \& Soft copies & $25 \%$ \\
\hline
\end{tabular}

\subsubsection{Human Resource Management}

The findings in Table 11 shows that $8 \%$ of the cooperatives do not employ but use members to contribute in terms of workforce, while 33\% employ only one person, $42 \%$ employ between 2 and 5 employees. Table 11 also shows that $33 \%$ of the cooperatives had turnover of 8 employees (cumulatively) in the past 6 months. Fifty percent had 
turnover of 16 employees (cumulatively) in the past 1 year and $42 \%$ had turnover of 12 employees (cumulatively) in the past 3 years.

Further, in $18 \%$ of the cooperatives the average employee term of office is less than 1 year, in $64 \%$ it is between 2 and 6 years and in $9 \%$ it is above 9 years. The table indicates that $42 \%$ of the cooperatives sponsored one employee each for training in the past 2 years. Finally, rate of accidents reported is very low as only $9 \%$ indicated that accidents are reported at least once a month, $9 \%$ at least once a quarter but for majority (64\%), accidents are rarely reported with $18 \%$ indicating that accidents have never been reported.

The findings paint a picture of micro and small cooperatives with less than 20 employees. Turnover is very high with more than $83 \%$ reporting a total employee turnover of 24 employees in the past 1 year. This would reduce consistency, specialization and transition in the cooperatives. Average term of office is also very short as $82 \%$ of the employees do not last 5 years. Even though absenteeism does not present a challenge to the cooperatives, employee capacity building is very low as only one employee in each of the $42 \%$ of the cooperatives have undergone work related training in the past 2 years. They may require more capacity building for the cooperatives to remain competitive. Low cases of accidents reported indicates an industry with low complications and simple straightforward operating procedures.

Table 14: Human Resources Management

\begin{tabular}{|l|l|l|}
\hline Statement & Variable & Score \\
\hline \multirow{4}{*}{ Workforces } & 0 employees & $8 \%$ \\
\cline { 2 - 3 } & 1 employees & $33 \%$ \\
\cline { 2 - 3 } & $2-5$ employees & $42 \%$ \\
\hline \multirow{4}{*}{ Turnover } & Past 6 months (8 employees) & $33 \%$ \\
\cline { 2 - 3 } & Past 1 years (16 employees) & $50 \%$ \\
\cline { 2 - 3 } & Past 3 years (12 employees) & $42 \%$ \\
\hline \multirow{3}{*}{ Average employees' term of office } & $<1$ years & $18 \%$ \\
\cline { 2 - 3 } & $2-5$ years & $64 \%$ \\
\cline { 2 - 3 } & $6-9$ years & $0 \%$ \\
\cline { 2 - 3 } & $>9$ years & $9 \%$ \\
\hline Average employee absenteeism & Per month & $0 \%$ \\
\hline No. of scholarships (employees) & 1 employee in past 2 years & $42 \%$ \\
\hline Rate of accident reports & Monthly & $9 \%$ \\
\cline { 2 - 3 } & Quarterly & $9 \%$ \\
\cline { 2 - 3 } & Rarely & $64 \%$ \\
\cline { 2 - 3 } & Never & $18 \%$ \\
\hline
\end{tabular}

\subsubsection{Entrepreneurial Traits}

\subsubsection{Innovativeness}

Table 12 indicates that only $17 \%$ of the cooperatives launched one new product (mala) in the past 3 years while $17 \%$ launched two products (mala \& yoghurt) in the past 3 years. All these products are still being sold by the cooperatives albeit not frequently. This shows low level of product innovativeness and marketing for new product penetrations. Findings indicate low level of product innovation. There is need for cooperative to diversify the products being sold, as there are many products that can be introduced for sale in line with milk products.

Table 15: Innovativeness

\begin{tabular}{|l|l|l|l|}
\hline Statement & Variable & Score & Remarks \\
\hline Number of products launched in the past 3 years & 1 & $17 \%$ & Mala \\
\cline { 2 - 4 } & 2 & $17 \%$ & Mala \& Yoghurt \\
\hline $\begin{array}{l}\text { Number of products launched in the past 3 years } \\
\text { but have been withdrawn }\end{array}$ & None & $100 \%$ & \\
\hline
\end{tabular}

\subsubsection{Creativity}

The study revealed that during seasons of milk glut, $58 \%$ of the cooperatives sell their excess milk through agents/outlets; $17 \%$ through hotels; $8 \%$ each sell by offering credit, hawking, reducing pries and distributing outside their locality. Table 13 also shows that generally $17 \%$ of the cooperatives adopt selling milk outside their localities as strategy for pushing for sales; $17 \%$ use bulk selling to institutions; $8 \%$ sell to brokers while $17 \%$ sell through outlets. The table also shows that $8 \%$ the respondents ranked the level of creativity in their cooperatives as high while $33 \%$ ranked creativity at medium; $50 \%$ at low and $8 \%$ at very low. Since majority (58\%) ranked creativity as either low or very low the cooperatives have fairly low creativity. 
Table 16: Creativity

\begin{tabular}{|l|l|l|}
\hline Statement & Variable & Score \\
\hline Methods used to sell milk & Through agents/outlets & $58 \%$ \\
\cline { 2 - 3 } during glut (100\%) & Through hotels & $17 \%$ \\
\cline { 2 - 3 } & Credit sales & $8 \%$ \\
\cline { 2 - 3 } & Processors & $8 \%$ \\
\cline { 2 - 3 } & Hawking using bikes & $8 \%$ \\
\cline { 2 - 3 } & Reduce prices & $8 \%$ \\
\cline { 2 - 3 } & Distribute outside the region & $8 \%$ \\
\hline \multirow{3}{*}{$\begin{array}{l}\text { How the cooperative pushes } \\
\text { its soles) }\end{array}$} & Sell outside the region & $17 \%$ \\
\cline { 2 - 3 } & Bulk selling to institutions & $17 \%$ \\
\cline { 2 - 3 } & Brokers & $8 \%$ \\
\cline { 2 - 3 } & Use outlets & $17 \%$ \\
\hline \multirow{3}{*}{ Level of creativity } & High & $8 \%$ \\
\cline { 2 - 3 } & Medium & $33 \%$ \\
\cline { 2 - 3 } & Low & $50 \%$ \\
\cline { 2 - 3 } & Very low & $8 \%$ \\
\hline
\end{tabular}

\subsubsection{Risk Taking and Opportunity Identification}

Majority of the respondents (50\%) indicated that risk taking is low in their cooperatives while $33 \%$ indicated that risk taking is medium. Further, only $17 \%$ of the respondents indicated that their cooperative staff can effectively conduct situational analysis with majority (67\%) indicating that the staff are somehow effective in situational analysis. Moreover, $18 \%$ of the respondents indicated that their cooperative staff are not effective in opportunity identification while $46 \%$ indicated that the staff are somehow effective with $36 \%$ asserting that they are effective. Findings show that opportunity identification, risk taking and creativity is low among the members. This calls for training of the members of the cooperatives on entrepreneurial skills.

Table 17: Risk Taking

\begin{tabular}{|l|l|l|}
\hline Statement & Variable & Score \\
\hline Level of risk taking & High & $17 \%$ \\
\cline { 2 - 3 } & Medium & $33 \%$ \\
\cline { 2 - 3 } & Low & $50 \%$ \\
\hline \multirow{2}{*}{$\begin{array}{l}\text { Staff effectiveness in conducting } \\
\text { situational analysis }\end{array}$} & Not effective & $17 \%$ \\
\cline { 2 - 3 } & Somehow effective & $67 \%$ \\
\cline { 2 - 3 } $\begin{array}{l}\text { Staff effectiveness in opportunity } \\
\text { identification }\end{array}$ & Effective & $17 \%$ \\
\cline { 3 - 3 } & Not effective & $18 \%$ \\
\cline { 3 - 3 } & Somehow effective & $46 \%$ \\
\cline { 3 - 3 } & Effective & $36 \%$ \\
\hline
\end{tabular}

\subsubsection{Technical Skills}

The respondents were asked to indicate technical effectiveness of cooperative staff members. On average Table 15 shows that majority of the respondents (44\%) showed that the staff are not effective while $33 \%$ indicated that they are somehow effective.

Table 18: Technical Capacity

\begin{tabular}{|l|l|l|l|l|}
\hline Factor & Not effective & Somehow effective & Effective & Very effective \\
\hline Accounting & $36 \%$ & $36 \%$ & $18 \%$ & $9 \%$ \\
\hline Financial Planning & $55 \%$ & $18 \%$ & $18 \%$ & $9 \%$ \\
\hline Resource mobilization & $55 \%$ & $18 \%$ & $18 \%$ & $9 \%$ \\
\hline Raw material sourcing & $36 \%$ & $36 \%$ & $18 \%$ & $9 \%$ \\
\hline Inventory control & $27 \%$ & $45 \%$ & $18 \%$ & $9 \%$ \\
\hline Pricing & $27 \%$ & $27 \%$ & $36 \%$ & $9 \%$ \\
\hline Product promotion & $45 \%$ & $55 \%$ & $0 \%$ & $0 \%$ \\
\hline Product development & $73 \%$ & $27 \%$ & $0 \%$ & $0 \%$ \\
\hline Average Score & $\mathbf{4 4 \%}$ & $\mathbf{3 3 \%}$ & $\mathbf{1 6 \%}$ & $\mathbf{7 \%}$ \\
\hline
\end{tabular}




\subsection{Performance}

4.6.1 Net Profits

Figure 13 shows that $17 \%$ of the cooperatives made losses in the past financial year, $25 \%$ broke even; $25 \%$ made profits of between Ksh. 20,000 and 40,000; 8.3\% made profits of between Ksh. 100,000 and 150,000; and 24.9\% made profits above Ksh. 1 million. Findings indicate that most cooperatives were operating at a loss with only $8.3 \%$ making profits between Ksh. 100,000-150,000. This indicates an issue in costing and pricing of their products. Need to train members on pricing and costing.

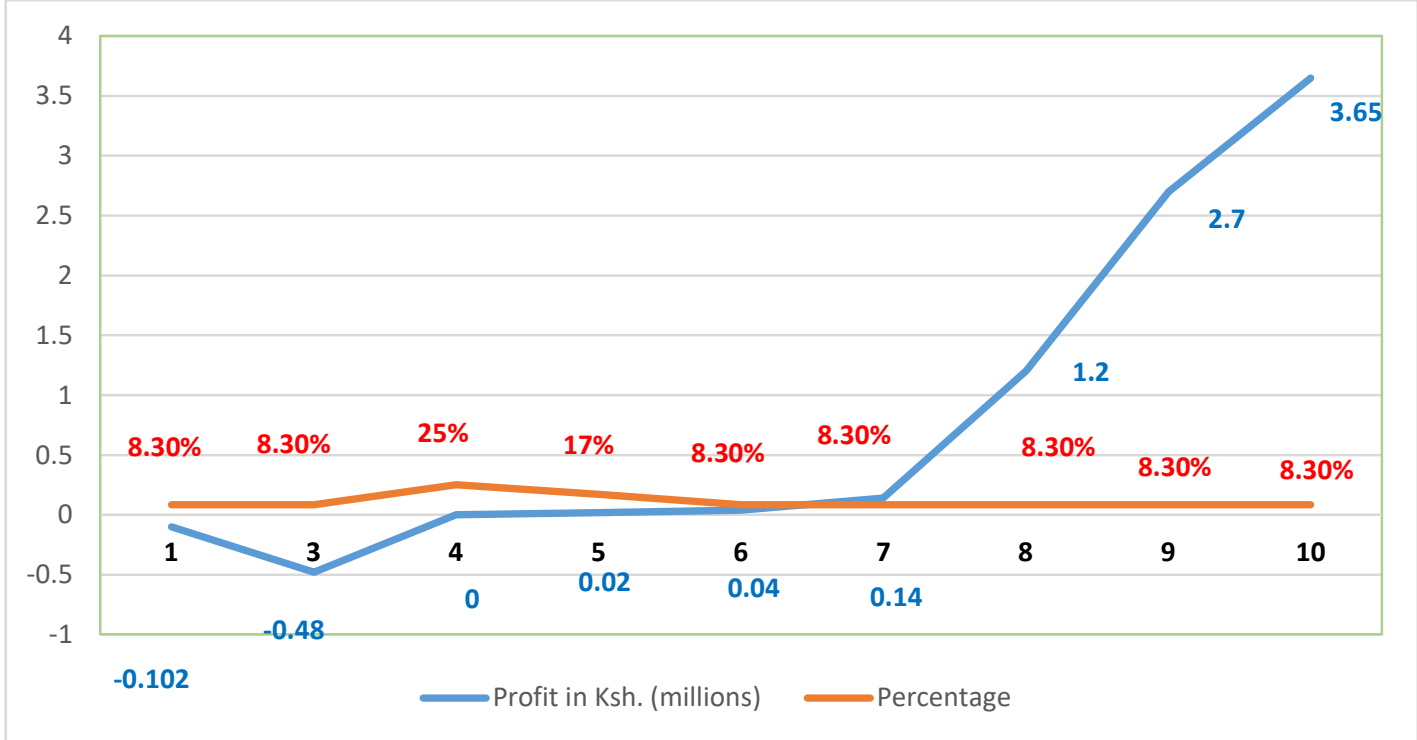

Figure 13: Profits

\subsubsection{Average Sales Growth}

The findings illustrated that $8.3 \%$ of the cooperatives registered negative growth rate of sales in the past one year while $50 \%$ did not register any growth. Eight point three percent registered growth of less than $5 \%$ while $16.6 \%$ recorded growth above $5 \%$.

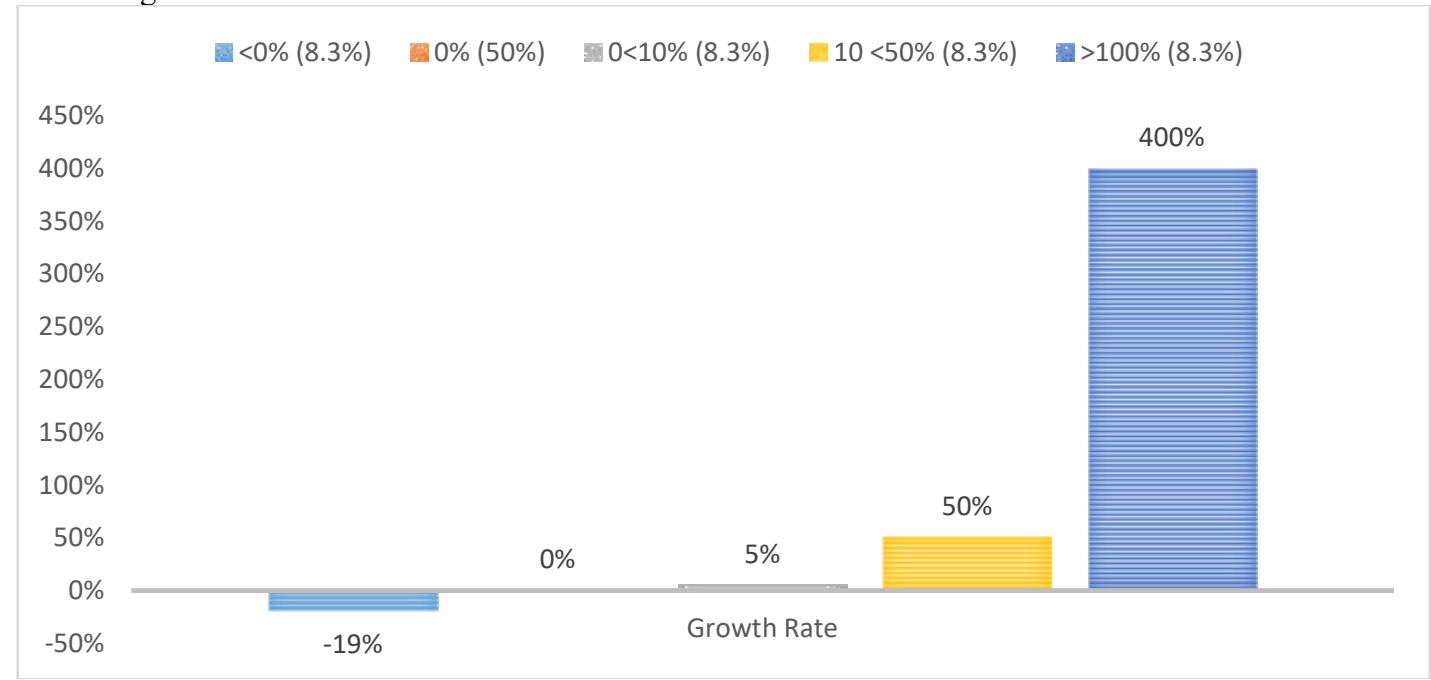

Figure 14: Sales Growth

\subsubsection{Market Share}

Forty percent of the cooperatives hold less than $20 \%$ of market share in their localities while $30 \%$ command between 20 and $40 \%$ market share; and $20 \%$ of the cooperatives holding between 41 and $60 \%$ of the market in their localities. 


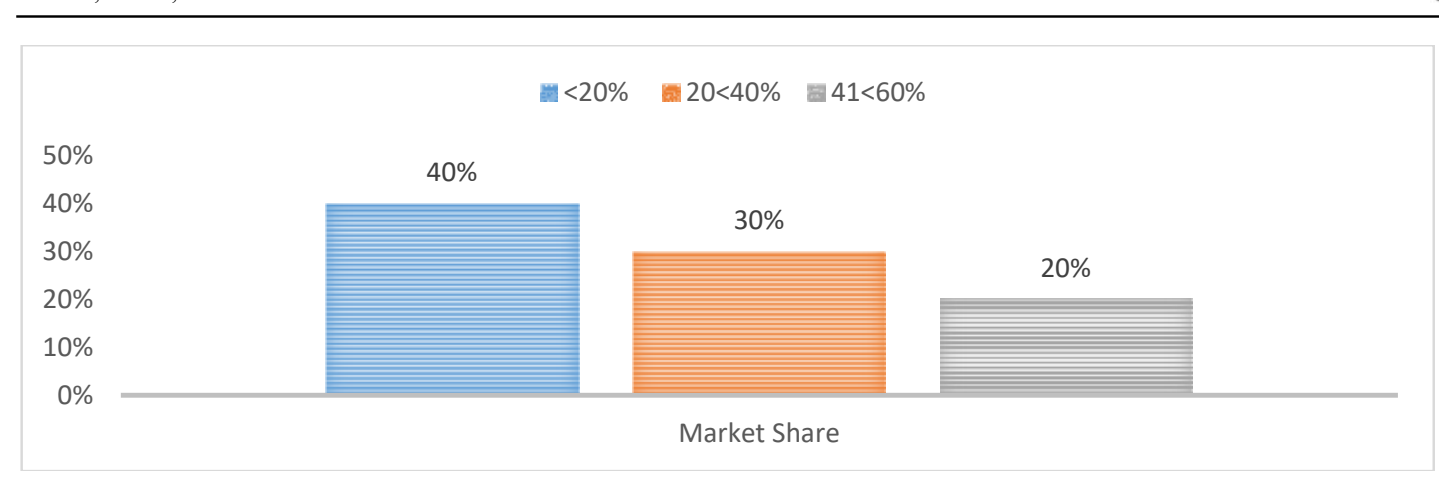

\section{Figure 15: Market Share}

\subsubsection{Efficiency and Effectiveness}

The respondents were asked to rank their cooperatives based on the level of efficiency and effectiveness. Twentyfive percent indicated that their cooperatives operate below $20 \%$ efficiency while $42 \%$ reported efficiencies of between 21 and 40\%; 25\%-reported efficiencies of between 41 and $60 \%$ and $8 \%$ reported efficiencies between 81 and $100 \%$.

Table 16 also shows that one third of the respondents indicated that their cooperatives are less than $20 \%$ effective in delivering their operational objectives; $25 \%$ indicated that the cooperative between 21 and $40 \%$ effectiveness; $33 \%$ scoring effectiveness at between 41 and $60 \%$; and $8 \%$ indicating that their cooperatives are between 61 and $80 \%$ effective in achieving their operational objectives.

Figure 16: Efficiency and Effectiveness

\begin{tabular}{|l|l|l|l|l|l|}
\hline Factor & $\mathbf{2 0 \%}$ & $\mathbf{2 1 - 4 0 \%}$ & $\mathbf{4 1 - 6 0 \%}$ & $\mathbf{6 1 - 8 0 \%}$ & $\mathbf{8 0 - 1 0 0 \%}$ \\
\hline Efficiency & $25 \%$ & $42 \%$ & $25 \%$ & $0 \%$ & $8 \%$ \\
\hline Effectiveness & $33 \%$ & $25 \%$ & $33 \%$ & $8 \%$ & $0 \%$ \\
\hline Average Score & $\mathbf{2 9 \%}$ & $\mathbf{3 4 \%}$ & $\mathbf{2 9 \%}$ & $\mathbf{4 \%}$ & $\mathbf{4 \%}$ \\
\hline
\end{tabular}

\subsubsection{Operational Performance}

Finally, the respondents were asked to describe operational performance in their cooperatives. As shown in Figure $17,83 \%$ indicated that their cooperatives sometimes fail to meet customers' demands while $17 \%$ indicated that they often fail to meet customer demands.

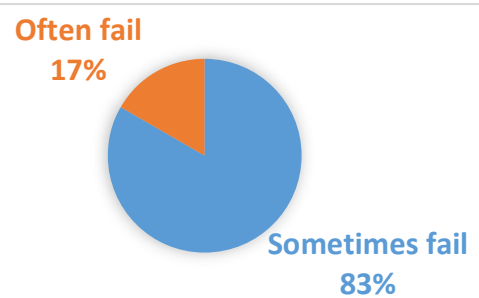

Figure 17: Operational Performance

\subsection{Effect of Entrepreneurial Competencies on Performance}

The study sought to establish the effect of entrepreneurial competencies on performance of dairy cooperatives in Machakos County. Specifically, the study evaluated the effects of managerial competencies, entrepreneurial traits and technical skills. An average continuous score was calculated for each variable and means were compared using student t-test due to the small population size. Each variable had a continuous score ranging from 1 to 5 . Thus, 3 was used as the cutoff point where values below 3 represented low capacity while values above three represented high capacity.

\subsubsection{Managerial Competencies}

A t-test was performed and there was no evidence of a statistically significant difference in mean managerial competency score between the two groups (low versus high managerial competency), $t(10)=-0.83, p=0.426$. Although the difference in mean managerial competency score between the groups was -0.4 , indicating that the group randomized to high managerial competency score was, on average resulted into slightly lower performance. A scenario contradicting the study hypothesis. However, this was not statistically significant. 
Table 19: T-test on Managerial Competency

\begin{tabular}{|c|c|c|c|c|c|c|c|c|c|c|}
\hline \multicolumn{11}{|c|}{ Group Statistics } \\
\hline & & \multicolumn{2}{|c|}{$\begin{array}{l}\text { Managerial } \\
\text { Competency }\end{array}$} & \multicolumn{2}{|l|}{$\mathrm{N}$} & Mean & \multicolumn{2}{|c|}{ Std. Deviation } & \multicolumn{2}{|c|}{ Std. Error Mean } \\
\hline \multirow{2}{*}{\multicolumn{2}{|c|}{ Performance }} & \multicolumn{2}{|l|}{$>=3.00$} & \multicolumn{2}{|l|}{3} & 1.9333 & \multicolumn{2}{|l|}{.50332} & \multicolumn{2}{|l|}{.29059} \\
\hline & & \multicolumn{2}{|l|}{$<3.00$} & \multicolumn{2}{|l|}{9} & 2.3333 & \multicolumn{2}{|l|}{.76811} & \multicolumn{2}{|l|}{.25604} \\
\hline \multicolumn{11}{|c|}{ Independent Samples Test } \\
\hline & & \multicolumn{2}{|c|}{$\begin{array}{l}\text { Levene's } \\
\text { Test for } \\
\text { Equality of } \\
\text { Variances }\end{array}$} & \multicolumn{7}{|c|}{ t-test for Equality of Means } \\
\hline & & \multirow[t]{2}{*}{$\mathrm{F}$} & \multirow[t]{2}{*}{ Sig. } & \multirow[t]{2}{*}{$\mathrm{t}$} & \multirow[t]{2}{*}{ df } & \multirow[t]{2}{*}{$\begin{array}{l}\text { Sig. } \\
(2- \\
\text { tailed })\end{array}$} & \multirow[t]{2}{*}{$\begin{array}{l}\text { Mean } \\
\text { Difference }\end{array}$} & $\begin{array}{l}\text { Std. Error } \\
\text { Difference }\end{array}$ & \multicolumn{2}{|c|}{\begin{tabular}{|l|}
$95 \%$ \\
Confidence \\
Interval of the \\
Difference \\
\end{tabular}} \\
\hline & & & & & & & & & Lower & Upper \\
\hline \multirow[t]{2}{*}{ Performance } & $\begin{array}{l}\text { Equal } \\
\text { variances } \\
\text { assumed }\end{array}$ & .749 & .407 & -.83 & 10 & .426 & -.40000 & .48197 & $\begin{array}{l}- \\
1.4739\end{array}$ & .67390 \\
\hline & $\begin{array}{l}\text { Equal } \\
\text { variances } \\
\text { not } \\
\text { assumed }\end{array}$ & & & -1.0 & 5.484 & .345 & -.40000 & .38730 & $\begin{array}{l}- \\
1.3697\end{array}$ & .56971 \\
\hline
\end{tabular}

From the findings we conclude that there was no evidence of a statistically significant difference in mean managerial competency score between the two groups, although the true difference is likely to lie somewhere between 1.0 points higher in the high managerial competency group and 1.5 points higher in the low entrepreneurial competency group. This indifference would be due to the fact that majority of persons managing the cooperatives do not have any specialized training in dairy cooperative management as exhibited in section 4.3. Thus, there was no unique managerial skill base to elicit significant difference in performance.

\subsubsection{Entrepreneurial Traits}

A t-test was performed and there was evidence of a statistically significant difference in mean entrepreneurial traits score between the two groups (low versus high entrepreneurial traits), $t(10)=3.092, p=0.011$. The difference in mean entrepreneurial traits score between the groups was 1.28 , indicating that the group randomized to high entrepreneurial traits score was, on average resulted into slightly higher performance.

Table 20: T-test on Entrepreneurial Traits

\begin{tabular}{|c|c|c|c|c|c|c|c|c|c|c|}
\hline \multicolumn{11}{|c|}{ Group Statistics } \\
\hline & & \multicolumn{2}{|c|}{$\begin{array}{l}\text { Entrepreneuri } \\
\text { al Traits }\end{array}$} & \multicolumn{2}{|l|}{$\mathrm{N}$} & Mean & \multicolumn{2}{|c|}{ Std. Deviation } & \multicolumn{2}{|c|}{ Std. Error Mean } \\
\hline \multirow{2}{*}{\multicolumn{2}{|c|}{ Performance }} & \multicolumn{2}{|c|}{$>=3.00$} & \multicolumn{2}{|l|}{2} & \multirow{2}{*}{$\begin{array}{l}3.3000 \\
2.0200\end{array}$} & \multicolumn{2}{|c|}{.70711} & \multicolumn{2}{|l|}{.50000} \\
\hline & & \multicolumn{2}{|c|}{$<3.00$} & \multicolumn{2}{|l|}{10} & & \multicolumn{2}{|c|}{.51164} & \multicolumn{2}{|l|}{.16180} \\
\hline \multicolumn{11}{|c|}{ Independent Samples Test } \\
\hline & & \multicolumn{2}{|c|}{$\begin{array}{l}\text { Levene's Test } \\
\text { for Equality } \\
\text { of Variances }\end{array}$} & \multicolumn{7}{|c|}{ t-test for Equality of Means } \\
\hline & & \multirow[t]{2}{*}{$\mathrm{F}$} & \multirow[t]{2}{*}{ Sig. } & \multirow[t]{2}{*}{$\mathrm{t}$} & \multirow[t]{2}{*}{$\mathrm{df}$} & \multirow[t]{2}{*}{$\begin{array}{l}\text { Sig. } \\
\text { tailed) }\end{array}$} & \multirow[t]{2}{*}{$\begin{array}{l}\text { Mean } \\
\text { Differenc } \\
\text { e }\end{array}$} & \multirow[t]{2}{*}{$\begin{array}{l}\text { Std. Error } \\
\text { Differenc } \\
\text { e }\end{array}$} & \multicolumn{2}{|c|}{$\begin{array}{l}95 \% \text { Confidence } \\
\text { Interval of the } \\
\text { Difference }\end{array}$} \\
\hline & & & & & & & & & Lower & Upper \\
\hline \multirow[b]{2}{*}{ 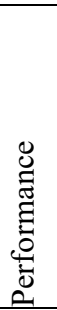 } & $\begin{array}{l}\text { Equal } \\
\text { variance } \\
\mathrm{S} \\
\text { assumed }\end{array}$ & .254 & .625 & 3.092 & 10 & .011 & 1.28000 & .41396 & .35765 & $\begin{array}{l}2.2023 \\
5\end{array}$ \\
\hline & $\begin{array}{l}\text { Equal } \\
\text { variance } \\
\mathrm{S} \quad \text { not } \\
\text { assumed }\end{array}$ & & & 2.436 & 1.219 & .210 & 1.28000 & .52553 & -3.13533 & $\begin{array}{l}5.6953 \\
3\end{array}$ \\
\hline
\end{tabular}


From the findings, we conclude that there was evidence of a statistically significant difference in mean entrepreneurial traits score between the two groups. The true difference is likely to lie somewhere between 2.0 points higher in the high entrepreneurial traits group and 0.3 points higher in the low entrepreneurial traits group.

\subsubsection{Technical Skills}

A t-test was performed and there was evidence of a statistically significant difference in mean technical skills score between the two groups (low versus high technical skills), $t(10)=3.034, p=0.013$. The difference in mean technical skills score between the groups was 1.7, indicating that the group randomized to high technical skills score was, on average resulted into slightly higher performance.

Table 21: Technical Skills

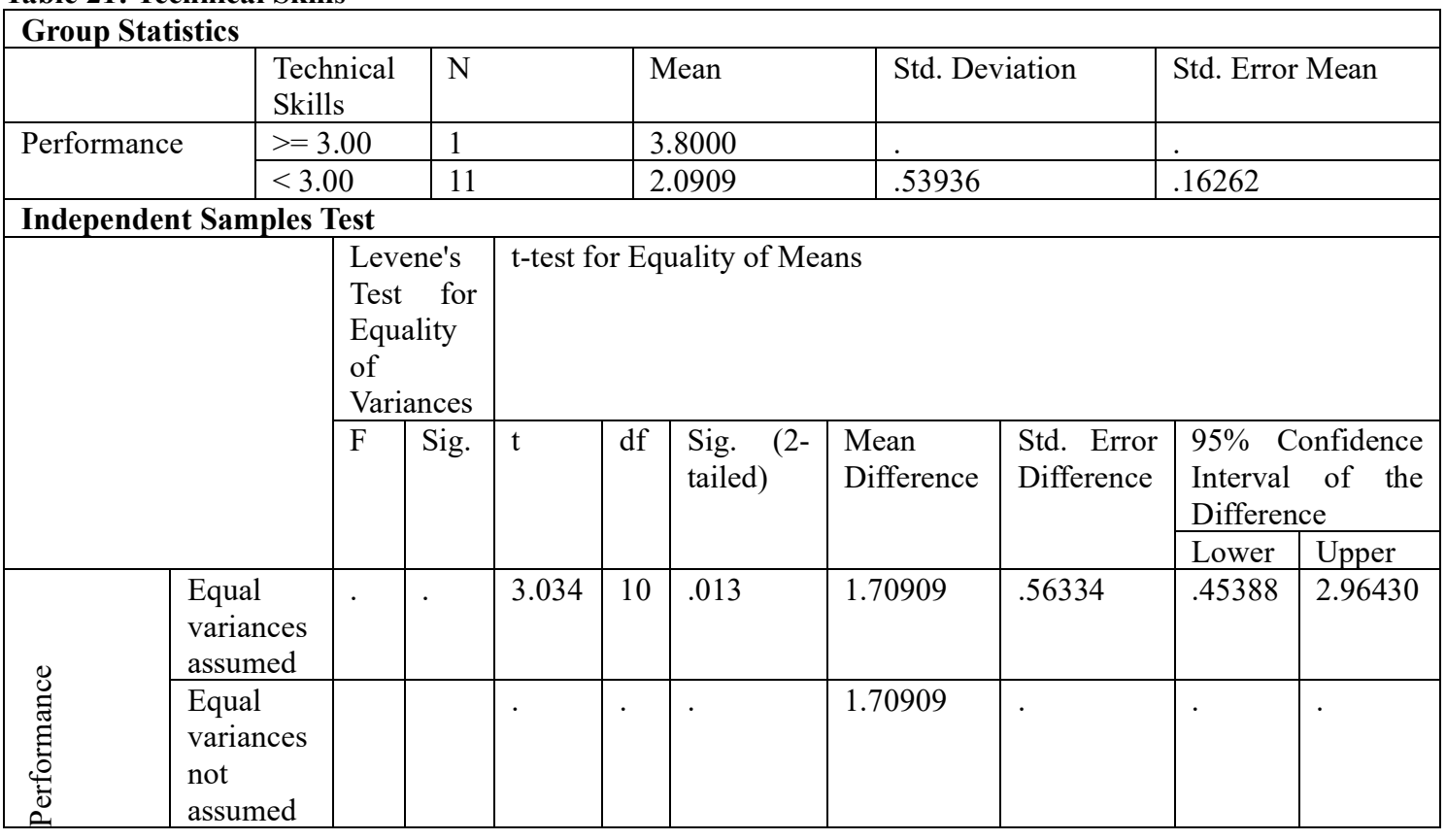

From findings, we conclude that there was evidence of a statistically significant difference in mean technical skills score between the two groups. The true difference is likely to lie somewhere between 3.0 points higher in the high technical skills group and 0.5 points higher in the low technical skills group.

\section{Conclusions and Recommendations}

The study concludes that there is inadequacies in corporate governance in most of the dairy cooperatives in Machakos County, Kenya. Majority of the boards have failed to adopt good corporate governance. Majority of the board members are old with limited representation of the youth. Board members over stay in their positions consecutively serving for more than the allowed 2 terms. Majority of the boards lack diversity, female are not adequately represented (men are more than two-thirds). No functional sub committees to offer oversight in most of the boards. Most board members have low academic qualification and lack specialized training in the roles that they play. These shortcomings inversely effect effective functioning of the boards and overall performance of the cooperatives.

Based on the first study objective, the study concludes that there lacks sufficient evidence to show that managerial competencies have an effect on performance of dairy cooperatives in Machakos County. Firstly, the indifference was because none of the dairy cooperatives had an operational business plan with lack of operational business plans leading to more than half of the cooperatives failing to meet their customers demand on a daily basis. A manifestation of poor planning to balance customer demands versus sourcing of adequate raw materials (milk). Secondly, only $17 \%$ of the cooperatives have strategic plans whose implementation is less than $20 \%$. For cooperatives with strategic plans, the cooperative vision is not understood by the cooperative members but by just a few of the board members and the technical staff. Thirdly, majority of persons managing the cooperatives do not have any specialized training in dairy cooperative management. Thus, there was no unique managerial skill base to elicit significant difference in performance. Further, findings paint a picture of micro and small cooperatives with very high employee turnover and very low employee managerial capacity.

Based on the second study objective, the study concludes that there is adequate evidence to show that 
entrepreneurial traits have positive effects on performance of dairy cooperatives in Machakos County. Despite, the study highlighted certain critical shortcoming in the industry. There is low level of product innovativeness and diversification. The findings show that only $17 \%$ of the cooperatives launched at least one new product in the past 3 years. The sale of these products are however very infrequent, indicating low level of product innovation in the sector. Further, most cooperatives suffer from low creativity and low risk taking initiatives by the cooperative members, board members and employees. Moreover, there is very limited capacity among dairy cooperative staff on situational analysis and effectiveness in opportunity identification. Shortcomings, which hinder optimal performance.

Based on the third study objective, the study concludes that there is adequate evidence to show that technical skills have positive effects on performance of dairy cooperatives in Machakos County. The study however, indicated that majority of the staff are not as effective in financial management (e.g. financial planning, accounting, record keeping, resources mobilization); procurement (raw material sourcing, inventory control); production (processing, diversification, product development); and marketing (pricing, product promotion). Particularly for marketing, the cooperatives rarely advertise, neither do they do structured market survey leading to low market penetration and numerous customer complaints (20\% complaints for daily sales). These inadequacies have been linked to employees' low academic qualification and lack of training.

The study therefore recommends development, adoption and full implementation of business and strategic plans for the dairy cooperatives in Machakos County for them to attain sustainable competitiveness. This will enable the management to establish specific objectives to be attained by the cooperatives, specific activities to be carried out, specific time lines and specific resources to be utilized by the cooperatives. This would lead to growth in performance. Strategically, cooperative vision should be promoted to all cooperative members, board members and employees to create strategic alignment in the businesses and its operations.

Further, the study recommends data based product development and diversification. That is, the cooperatives should conduct frequent and structured market surveys to inform product development and diversification. The study also recommends training to build capacity for creativity, risk taking, situational analysis and opportunity identification among the members, board members, managers and employees. The trainings will be particularly important in enabling the cooperatives identify existing and new business opportunities.

Moreover, the study recommends training to enhance employees' capacity and effectiveness in financial management (e.g. financial planning, accounting, record keeping, resources mobilization); procurement (raw material sourcing, inventory control); production (processing, diversification, product development); and marketing (pricing, product promotion). Particularly, loss of revenue due to spoilage of milk can be controlled by training on best processing and quality control methods while training on marketing, would be critical in enhancing product penetration, reducing customer complaints and stimulating positive growth.

For further research, the study recommends widening the scope of the study to compare Machakos to other parts of the Country. There is also need to investigate the reasons for high labor turnover and poor public relations between the cooperatives and communities surrounding them.

\section{REFERENCES}

CBK. (2018). Annual GDP. Retrieved 09 23, 2018, from Central Bank of Kenya: https://www.centralbank.go.ke/annual-gdp/

DAFS. (2017). Annul Report. Machako: Machakos County.

Dana, L. P., \& Schoeman, J. (2010). An entrepreneurial innovation: Mega cooperatives. Asia Pacific Journal of Innovation and Entrepreneurship, 4(1), 67-87.

Díaz-Pichardo, R., Cantú-González, C., López-Hernández, P., \& McElwee, G. (2012). From farmers to entrepreneurs: The importance of collaborative behavior. Journal of Entrepreneurship, 21(1), 91-116.

FAO. (2018). Kenya at a glance. Retrieved 09 23, 2018, from FAO in Kenya: http://www.fao.org/kenya/faoin-kenya/kenya-at-a-glance/en/

GOK. (2012). Kenya national dairy master plan volume I: Situational analysis of the dairy sub-sector. Nairobi: Government Printers.

GOK. (2018). Livestock Statistics 2018. Nairobi, KE: State Department of Livestock.

IGAD. (2013). The Contribution of Livestock to the Kenyan Economy [ICPALD 4/CLE/8/2013]. Nairobi, KE: IGAD Centre for Pastoral Areas and Livestock Development (ICPALD).

Muriithi, M. K., Huka, G. S., \& Njati, I. C. (2014). Factors influencing growth of dairy f arming business in Amentia South District of Mere County, Kenya. Journal of Business and Management, 16(4 (2)), 2131.

Muriuki, H. (2011). Dairy development in Kenya. Rome: FAO. 
Mwangi, R. W. (2013). Factors influencing dairy cooperative societies performance in Mathira and Kieni constituencies, Nyeri County, Kenya. Nairobi, KE: Masters Thesis, Department of Public Health, Pharmacology and Toxicology, University of Nairobi.

Osewe, D., Kharde, P., \& Kipsat, M. (2016). Entrepreneurial behaviour of dairy groups in Nyamira county, Kenya: A sustainable livelihood strategy for rural development . Asian Journal of Agricultural Extension, Economics \& Sociology, 13(2), 1-8.

Reddy, R. (2014). Women entrepreneurship in rural areas: A study of Mulkanoor women cooperative dairy. Journal of Economics and Finance, 5(2), 52-56.

Shangurai, C. (2013). Evaluation of Hamaruomba smallholder dairy cooperative for improved dairy value chain: A case study of Mushagashe area in Masvingo district, Zimbabwe. Wageningen: Masters Thesis, Van Hall Larenstein University of Applied Sciences.

Tabesh, H., \& Pourmontahari, F. (2013). Comparing two formulas for sample size determination for prevalence studies. Iranian Journal of Health Sciences, 1(2), 56- 60.

Waitituh, J. A. (2017). Smallholder dairy production in Kenya; a review. Livestock Research for Rural Development, 29(7). 